\title{
KOROVKIN TYPE ERROR ESTIMATES FOR MEYER-KÖNIG AND ZELLER OPERATORS
}

\author{
OCTAVIAN AGRATINI
}

\begin{abstract}
In this paper we construct a linear and positive approximation process of discrete type which includes as a particular case the Meyer-König and Zeller operators. Based on several inequalities we prove that the sequence converges to the identity operator. We obtain inequalities regarding estimations of the remainder which are given by using the moduli of smoothness of first and second order as well as the Lipschitz type maximal function. Also we establish that our operators have the variation diminishing property.
\end{abstract}

Mathematics subject classification (2000): 41A36, $26 \mathrm{D} 07$.

Key words and phrases: linear and positive operators, moduli of smoothness, variation diminishing property, Lipschitz type maximal function.

\section{REFERENCES}

[1] U. ABEL, The complete asymptotic expansion for the Meyer-König and Zeller Operators, Journal of Math. Analysis and Applications 208(1997), 109-119.

[2] J. A. H. ALKEMADE, The second moment for the Meyer-König and Zeller operators, J. Approx. Theory, 40(1984), 261-273.

[3] F. Altomare AND M. CAmPITI, Korovkin-Type Approximation Theory and Its Applications, de Gruyter Series Studies in Mathematics, Vol.17, Walter de Gruyter, Berlin-New York, 1994.

[4] M. BECKER AND J. NeSSEL, A global approximation theorem for Meyer-König and Zeller operators, Math. Z., 160(1978), 195-206.

[5] Wenzhong Chen, On the integral type Meyer-König and Zeller operators, Approx. Theory and Its Applications, 2(1986), 3, 7-18.

[6] E. W. Cheney And A. Sharma, Bernstein power series, Canad. J. Math., 16(1964), 241-253.

[7] OGÜN DŏGRU, Approximation order and asymptotic approximation for generalized Meyer-König and Zeller operators, Mathematica Balkanica, New Series vol. 12(1998), 3-4, 359-367.

[8] I. GAVREA AND I. RAŞA, Remarks on some quantitative Korovkin-type results, Revue d'Analyse Num. et de Theorie de l'Approx., 22(1993), 2, 173-176.

[9] H. H. GonsKA, Quantitative Korovkin type theorems on simultaneous approximation, Math. Z., 186(1984), 419-433.

[10] Xu JiHua AND Li LuOQIng, Converse theorems on approximation by integral type Meyer-König and Zeller Operators, in "Progress in Approximation Theory" (P. Nevai and A. Pinkus Eds.) Academic Press, Boston, 1991, 899-911.

[11] B. LenZE, On Lipschitz-type maximal functions and their smoothness spaces, Proc. Netherland Acad. Sci. A 91(1988), 53-63.

[12] A. LuPAŞ AND M. W. MÜLLER, Approximation properties of the $M_{n}$-operators, Aequationes Math., 5(1970), 19-37.

[13] M. W. MÜLLER, L $L_{p}$-approximation by the method of integral Meyer-König and Zeller operators, Studia Math., 63(1978), 81-88.

[14] I. J. SCHOENBERG, On variation diminishing approximation methods, In: On Numerical Approximation (Proc. Sympos. Conducted by the MRC; ed. R. E. Langer), Madison, Univ. of Wisconsin Press 1959, 249-274. 
[15] P. C. SIKKEMA, On some linear positive operators, Indag. Math., 32(1970), 327-337.

[16] V. TотіK, Approximation by Meyer-König and Zeller type operators, Math. Z., 182(1983), 425-446. 